\title{
СТАН ПРО- І АНТИОКСИДАНТНОЇ СИСТЕМ КРОВІ У ХВОРИХ НА ОСТЕОАРТРОЗ КРІЗЬ ПРИЗМУ ПОЛІ- ТА КОМОРБІДНОСТІ У ВІКОВОМУ АСПЕКТІ
}

Вищий державний навчальний заклад України «Буковинський державний медичний університет», м. Чернівці

Резюме. У статті досліджено особливості змін параметрів про- і антиоксидантної систем у 120 хворих на остеоартроз (ОА) у контексті вікових явищ коморбідності та поліморбідності упродовж одномісячного терміну стандартного лікування. Встановлено, що зі збільшенням віку хворих на ОА поряд із зростанням системності уражень суглобів і тяжкістю перебігу ОА зростає кількість і вираженість коморбідних процесів, серед яких найбільшу увагу надано явищам, що формують метаболічний синдром. У період загострення ОА у всіх осіб відмічено значні прояви оксидантного стресу, які впродовж одномісячного терміну лікування при низькому рівні коморбідності та у віці до 50 років хара-

Вступ. Остеоартроз (ОА) - одне з найпоширеніших хронічних захворювань суглобів, що характеризується прогресуючим ураженням суглобового хряща, субхондральної кісткової тканини, зв'язок, капсули, синовіальної оболонки, періартикулярних тканин на тлі низькоінтенсивного запалення, супроводжується високим ступенем тимчасової втрати працездатності та стійкою інвалідністю [3, 7].

Рентгенологічні ознаки ОА виявляються в більшості осіб старше 65 років і біля $80 \%$ людей старше 75 років $[3,13]$. Частота ОА збільшується з віком залежно від статі: до 50-річного віку частіше хворіють чоловіки, після 50-річного - жінки, але загальне співвідношення чоловіки-жінки залежно від контингенту складає 1:4-7 [6]. Проте нині достовірно доведено, що до появи рентгенологічних змін у суглобах упродовж років і навіть десятків років в організмі хворих виникають порушення на молекулярному, субклітинному рівнях. У доклінічній стадії аномалії суглобів можна виявити більш точними методами: як магнітнорезонансна томографія, ультрасонографія, сцинтиграфія кісток $[7,8]$. Попри численні пошуки нових підходів до діагностики та лікування ОА на основі поглибленого вивчення уражень опорно-рухового апарату, в останні $10-15$ років підвищена увага зосереджена на ролі коморбідних процесів у хворих на ОА як із позиції патогенетичних взаємин між ними, так і реалізації визначених на засадах доказової медицини програм лікування ОА $[1,8,9,12]$. Саме багатоваріантність коморбідних процесів у хворих на ОА, складність оцінки їх взаємин на різних рівнях, у різних вікових періодах зумовила відсутність на теперішній час гайдлайнів із рекомендаціями лікування таких пацієнтів [6]. Слід відзначити, що донині немає чітких дефініцій коморбідності, але визначено, що коморбідність може мати клінічно оче- ктеризувалися хорошою зворотністю. При зростанні кількості та вираженості коморбідних процесів та у віці старше 50-60 років відмічалася зростаюча резистентність до зворотності параметрів про- і антиоксидантних систем крові. Таку ж тенденцію відзначено щодо показників системного низькоінтенсивного запалення. Гендерних відмінностей змін досліджуваних параметрів не відзначено. Обгрунтовується потреба в додатковому застосуванні антиоксидантних засобів у комплексному лікуванні хворих на ОА з явищами зростаючої кількості та вираженості коморбідних процесів.

Ключові слова: остеоартроз, коморбідність, оксидантний стрес, лікування.

видні зв'язки (як ішемічна хвороба серця (IXC) та артеріальна гіпертензія (АГ)), патогенетичну зумовленість (як метаболічний синдром і цукровий діабет чи атеросклероз тощо) та медикаментозно зумовлену залежність [1]. Є дискусії щодо методів оцінки та значення рівнів коморбідності [12]. В Україні подібні дослідження в цього контингенту хворих розпочаті з 2010 року [3, 6]. Однак відомо, що при будь-яких ураженнях внутрішніх органів розвиваються неспецифічні загальнопатологічні порушення різних рівнів, вираженість, тривалість і зворотність яких зумовлена сукупністю патологічних процесів, що і є однією з неспецифічних метаболічних ланок формування коморбідності. Одним із таких неспецифічних патологічних процесів $\epsilon$ порушення рівноваги про- $\mathrm{i}$ антиоксидантних систем крові (оксидативний стрес) [13]. Визначення особливостей стану проi антиоксидантних систем у хворих крізь призму вікових проявів коморбідності та поліморбідності може сприяти глибшому патогенетичному розумінню залежності між ними, а також обгрунтуванню відповідних корекцій в існуючі стандарти лікування.

Мета дослідження. Дослідити у крові хворих на ОА особливості змін параметрів про- i антиоксидантної систем крові в контексті вікових явищ полі- та коморбідності в динаміці лікування стандартними методами.

Матеріал і методи. Дослідженням охоплено 120 хворих на ОА в період загострення у віці 3775 років, серед яких жінок було 89 (74,17\%), чоловіків 31 (25,83 \%). Давність захворювання на OА була в межах 3-21 року. Верифікацію діагнозу OA здійснювали за рекомендаціями EULAR (2010) на основі даних клінічних, лабораторних та інструментальних досліджень [11]. Всі пацієнти в минулому неодноразово лікувалися 3 приводу загострень ОА в ревматологічних чи загально- 
терапевтичних стаціонарах. Діагнози коморбідних та поліморбідних процесів виставлялися згідно з відповідними наказами МОЗ України та підтверджені профільними фахівцями. Пацієнтам призначалося стандартне лікування ОА (нестероїдні протизапальні препарати (НПЗП), хондропротектори, гастропротектори, місцеве лікування) згідно з Наказом МОЗ України № 676 від 12.10.2006 з фаху “Ревматологія". За потреби додатково за рекомендаціями фахівців призначалися ліки з приводу коморбідних процесів (гіпотензивні, антиішемічні, антидіабетичні, гіполіпідемічні тощо).

У крові вивчали вміст глутатіону відновленого (ГВ) в еритроцитах титраційним методом за О.В. Травіною в модифікації І.Ф. Мещишена, I.В. Петрової [5], активність глутатіонпероксидази (ГП) та глутатіон-S-трансферази (ГТ) за I.Ф. Мещишеним [5], вміст малонового альдегіду (МА) у плазмі та еритроцитах - за методом Ю.А. Владимирова, А.Н. Арчакова [2]. Досліджували також маркери запалення С-реактивний протеїн (СРП) імуноферментним методом, ШОЕ та лейкоцитарний спектр крові загальноприйнятими методами. Обстеження проводили при надходженні чи первинному огляді, та через 30 днів від початку лікування.

Контрольну групу складали 30 практично здорових осіб (ПЗО) того ж віку та статі, які мали нормальні показники опорно-рухового апарату. Статистичну обробку результатів дослідження проводили на персональному комп'ютері за допомогою стандартних статистичних програм «Microsoft Excel» шляхом обчислення середньоарифметичної М та похибки середньоарифметичної - $\mathrm{m}$, достовірність відмінностей - Р за t-критерієм Стьюдента. Різницю показників при різних термінах дослідження вважали вірогідною при $\mathrm{P}<0,05$.

Результати дослідження та їх обговорення. Першим етапом у дослідженні була оцінка поширеності та вираженості явищ полі- та коморбідності в пацієнтів на віковому та гендерному аспекті. Ці дані наведені в таблиці 1.

Як видно 3 даних табл. 1, серед обстежених 120 хворих на ОА лише в 4 (3,33\%) осіб віком 37-43 роки не виявлено інших захворювань. Це були пацієнти, в яких визначальним фактором розвитку ОА було тривале постійне навантаження на суглоби (вантажники - три, бетонник один). Домінуючим віковим контингентом були пацієнти віком 50-60 років (43 особи - 35,83\%) та після 60 років (62 особи - 51,67\%). У гендерному аспекті у віці до 50 років дещо переважали чоловіки (9 із 15 осіб), у віковій групі 51-60 років - зростала кількість жінок (32 - 74,42 \%), особливо після 60 років $(51-82,25 \%)$, що загалом відповідає даним літератури $[3,6]$. У пацієнтів віком до 50 років переважали явища олігоостеоартрозу (зазвичай колінних суглобів, незалежно від статі), після 50, особливо 60 років - поліостеоартрозу. Домінували ураження колінних суглобів - у
96 із 105 пацієнтів у поєднанні з ОА кульшових 14 осіб (13,33\%), чи гомілковостопних (19 осіб 18,0 \%), суглобів кистей $(29-27,6$ \%). Рентгенологічно у всіх пацієнтів виявлено I-II стадії уражень колінних суглобів за класифікацією J.H.Kellgren, J.S.Lawrence. Зростання охопленості артрозним процесом кількості та вираженості ураження суглобів супроводжувалося погіршенням перебігу хвороби, частішими, тривалішими періодами загострення, збільшенням потреби в медикаментозній опіці, зниженням працездатності.

В аспекті полі- та коморбідності у віці до 50 років (табл.1) відмічалися легкі та помірні прояви артеріальної гіпертензії (АГ), хвороби системи травлення, ожиріння (ОЖ) та із поліморбідних хронічні обструктивні захворювання легенів (ХОЗЛ), ураження сечостатевої системи. Найчастіше виявляли одне, рідко два коморбідні та одне-два захворювання, що не мали доведених зв'язків з ОА.

У віці після 50, особливо 60 років (див. табл. 1) прогресивно зростали такі коморбідні процеси, як АГ, ішемічна хвороба серця (IXC), серцева недостатність, ожиріння, цукровий діабет типу 2 (ЦД), хвороби системи травлення, а із поліморбідних процесів - ХОЗЛ, ураження сечостатевої системи, шкіри, хвороб ЛОР-органів у період ремісії, депресивні стани. Із зазначеного спектра коморбідних процесів на особливу увагу заслуговують АГ, IXC, ОЖ, жирова хвороба печінки та ЦД, які в різних комбінаціях та в будь-якому випадку можна було оцінювати як метаболічний синдром (МС). Таких у нашому дослідженні виявлено 84 особи (70,0 \%). Нині визнано, що МС та OA мають тісні патогенетичні зв'язки [9, 14], включаючи значне підвищення кардіометаболічних і васкулярних ризиків у хворих на ОА як за такого коморбідного співіснування, так і за використання протиревматичних препаратів у лікувальних комплексах. У загальному можна відмітити суттєве зростання та високий рівень коморбідності у хворих на ОА старших вікових груп $[12,14]$.

Певної уваги заслуговувала поява і зростання частоти депресивних станів (18 осіб - 15,0 \%), особливо після 60 років (у два рази), ймовірно, як сумаційний прояв погіршення якості життя, розчарування потребами майже постійного лікування різних хвороб, можливих атеросклеротичних уражень судин головного мозку та соціальних факторів. Гендерних відмінностей поширеності та вираженості коморбідних і поліморбідних процесів в обстежених не виявлено, хоча в жінок ОА проходив тяжче.

3 позиції виявлених різних за спектром та залежністю коморбідних факторів оцінено стан про- і антиоксидантної систем крові в досліджуваних у зіставленні 3 доступними в клінічній практиці показниками запального процесу (СРП, ШОЕ, лейкоцитоз, лейкоформула), оскільки нині існують навіть категоричні міркування, що ОА це запальне захворювання [10]. Параметри зазначених процесів наведені в таблиці 2. 
Таблиця 1

Вікові особливості проявів коморбідності та поліморбідності у хворих на остеоатроз (n, \%)

\begin{tabular}{|c|c|c|c|c|}
\hline НОЗОЛОГІЯ & $\begin{array}{c}\text { вік до } 50 \text { років } \\
\mathrm{n}=15\end{array}$ & $\begin{array}{c}\text { вік 51-60 років } \\
n=43\end{array}$ & $\begin{array}{c}\text { старше } 60 \text { років } \\
\mathrm{n}=62\end{array}$ & $\begin{array}{l}\text { разом } \\
n=120\end{array}$ \\
\hline Без коморбідних явищ & $4(3,3 \%)$ & - & - & $4(3,3 \%)$ \\
\hline Артеріальна гіпертензія I ст. & $3(2,5 \%)$ & $4(3,33 \%)$ & - & $7(5,83 \%)$ \\
\hline Артеріальна гіпертензія II ст. & - & $32(26,67 \%)$ & $52(43,33 \%)$ & $84(70,07 \%)$ \\
\hline Ішемічна хвороба серця, помірні форми & - & $28(23,33 \%)$ & $18(15,0 \%)$ & $46(38,33 \%)$ \\
\hline \begin{tabular}{|c|} 
Ішемічна хвороба серця, виражені фор- \\
ми (3 порушенням серцевого ритму та \\
серцева недостатність) \\
\end{tabular} & & $3(2,50 \%)$ & $21(17,5 \%)$ & $24(20,0 \%)$ \\
\hline Ожиріння I ст. & $1(0,83 \%)$ & $2(1,66 \%)$ & $3(2,50 \%)$ & $5(4,17 \%)$ \\
\hline Ожиріння II-III ст. & - & $34(28,33 \%)$ & $46(38,33 \%)$ & $780(66,67 \%)$ \\
\hline Цукровий діабет 2-й тип & - & $7(5,83 \%)$ & $14(11,67 \%)$ & $21(17,5 \%)$ \\
\hline $\begin{array}{l}\text { Стеатогепатоз, } \\
\text { стеатогепатит }\end{array}$ & - & $34(28,33 \%)$ & $46(38,33 \%)$ & $80(66,67 \%)$ \\
\hline Хр. холецистит ( у т.ч. калькульозний) & $3(2,5 \%)$ & $38(31,67 \%)$ & $58(48,33 \%)$ & $96(80,0 \%)$ \\
\hline Гастрити, гаетродуоденіти & $7(5,83 \%)$ & $35(29,17 \%)$ & $52(43,33 \%)$ & $87(72,5 \%)$ \\
\hline Пептична виразка & - & $2(1,66 \%)$ & $4(3,33 \%)$ & $6(5,0 \%)$ \\
\hline Хр. панкреатит & $2(1,66 \%)$ & $9(7,50 \%)$ & $12(10,0 \%)$ & $21(17,5 \%)$ \\
\hline Ентероколопатії & - & $12(10,0 \%)$ & $17(14,17 \%)$ & $29(24,17 \%)$ \\
\hline Хр. пієлонефрит & - & $8(8,67 \%)$ & $12(10,0 \%)$ & $20(16,6 \%)$ \\
\hline Сечокам'яна хвороба & - & $1(0,83 \%)$ & $2(1,66 \%)$ & $3(2,5 \%)$ \\
\hline Хр. простатит & $2(1,66 \%)$ & $1(0,83 \%)$ & $1(0,83 \%)$ & $4(3,33 \%)$ \\
\hline Хр. аднексит & - & $3(2,53 \%)$ & $4(3,33 \%)$ & $7(5,83 \%)$ \\
\hline Хвороби ЛОР-органів & - & $3(2,53 \%)$ & $6(5,00 \%)$ & $9(7,5 \%)$ \\
\hline Депресивні стани & - & $6(5,00 \%)$ & $12(10,0 \%)$ & $18(15,0 \%)$ \\
\hline Хвороби шкіри & - & $2(1,66 \%)$ & $3(2,5 \%)$ & $5(4,17 \%)$ \\
\hline Хронічний бронхіт & $1(0,83 \%)$ & $3(2,50 \%)$ & $5(4,17 \%)$ & $8(8,67 \%)$ \\
\hline ХОЗЛ & $1(0,83 \%)$ & $2(1,66 \%)$ & $6(5,0 \%)$ & $8(8,67 \%)$ \\
\hline
\end{tabular}

Матеріали табл. 2 свідчать, що в період загострення ОА в крові у пацієнтів всіх вікових груп порівняно з ПЗО відмічалося однотипне відповідне підвищення інтенсивності пероксидного окиснення ліпідів (ПОЛ) за параметрами МА в плазмі та еритроцитах із тенденцією до більш вираженого у пацієнтів старших вікових груп із високим рівнем коморбідності, однак вони не були вірогідними між собою ( $>>0,05)$. Водночас всі досліжувані параметри антиоксидантної системи (ГВ, ГП, ГГ-6 ФДГ, ГР) були вірогідно порушені та вказували на ймовірну їх декомпенсацію, а в пацієнтів iз значними проявами жирової хвороби печінки (стеатогепатит) - параметри глутатіонової антиоксидантної системи, особливо ГВ (вірогідне зниження порівняно 3 хворими на ОА у віці до 50 років). Відомо, що ГВ - один із ключових чинників антиоксидантної системи крові, що володіє низкою інших функцій, зокрема забезпечення клітинного редокс-потенціалу будь-якої тканини, органа [4]. Він синтезується в печінці, використо- вується в різних метаболічних процесах, зокрема окисновідновних, нестача його в організмі за різних причин значно ослаблює опірність живих об'єктів [4]. Індивідуальний аналіз досліджуваних параметрів про- і антиоксидантної систем крові не дав можливості виявити вплив тих чи інших коморбідних процесів, а також вираженості і тяжкості перебігу OА на їхні значення. Певною мірою можна говорити про більш суттєвий вплив сукупності хвороб, що формують МС на дисбаланс про- i антиоксидантної системи крові, однак вірогідність цього впливу була менша лише за окремими параметрами (ГВ, МА). У порівняльному аспекті параметрів ПОЛ та антиоксидантної системи крові 3 групою хворих із мінімальними проявами коморбідності (у віці до 50 років) дозволяє нам зробити припущення, що певне зростання оксидативного стресу в крові зумовлено переважно зростанням рівня та вираженості коморбідних процесів.

Слід відзначити, що показники, які відображають інтенсивність запального процесу в орга- 
Таблиця 2

Динаміка параметрів про- і антиоксидантної систем крові, запального процесу у хворих на остеортроз залежно від вираженості явищ коморбідності і віку

\begin{tabular}{|c|c|c|c|c|c|}
\hline $\begin{array}{l}\text { Показники, } \\
\text { од. виміру }\end{array}$ & $\begin{array}{c}\text { Контрольна } \\
\text { група }\end{array}$ & $\begin{array}{c}\text { Відношення до } \\
\text { лікувального } \\
\text { процесу }\end{array}$ & $\begin{array}{c}\text { Мінімальна } \\
\text { коморбід- } \\
\text { ність, } \mathrm{n}=15\end{array}$ & $\begin{array}{c}\text { Значна коморбі- } \\
\text { дність, вік } \\
\text { 51-60 років, } \\
\text { n=43 }\end{array}$ & $\begin{array}{c}\text { Виражена комо- } \\
\text { рбідність, вік } \\
\text { понад } 60 \text { років, } \\
\text { n=62 }\end{array}$ \\
\hline \multirow{2}{*}{$\begin{array}{c}\text { Глутатіон відновле- } \\
\text { ний, ммоль/л }\end{array}$} & \multirow{2}{*}{$0,95 \pm 0,02$} & до лікування & $0,81 \pm 0,03 *$ & $0,71 \pm 0,02 *$ *\# & $0,67 \pm 0,04^{* / \#}$ \\
\hline & & після лікування & $0,89 \pm 0,02 * *$ & $0,77 \pm 0,04^{\text {нв }}$ & $0,73 \pm 0,03^{\text {нв }}$ \\
\hline \multirow{2}{*}{$\begin{array}{c}\text { Глутатіонперокси- } \\
\text { даза, нмоль ГВ за 1хв } \\
\text { на 1г Нв }\end{array}$} & \multirow{2}{*}{$72,4 \pm 4,86$} & до лікування & $98,4 \pm 4,77^{*}$ & $108,4 \pm 6,77^{*}$ & $132,2 \pm 8,42^{*}$ \\
\hline & & після лікування & $82,2 \pm 5,68 * *$ & $93,2 \pm 6,22^{* / \text { нв }}$ & 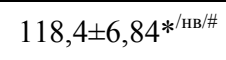 \\
\hline \multirow{2}{*}{$\begin{array}{c}\text { Глутатіон-S-транс- } \\
\text { фераза, нмоль за 1хв } \\
\text { на 1м білка }\end{array}$} & \multirow{2}{*}{$13,56 \pm 1,28$} & до лікування & $16,2 \pm 1,08$ & $21,6 \pm 0,92 *$ & $23,4 \pm 0,86^{* / \#}$ \\
\hline & & після лікування & $14,8 \pm 0,84$ & $17,4 \pm 0,56^{* *}$ & $19,6 \pm 0,62^{\#}$ \\
\hline \multirow{2}{*}{$\begin{array}{c}\text { МА плазми, } \\
\text { мкмоль/л }\end{array}$} & \multirow{2}{*}{$2,68 \pm 0,26$} & до лікування & $4,1 \pm 0,34^{*}$ & $5,4 \pm 0,37^{*}$ & $6,1 \pm 0,55^{* / \#}$ \\
\hline & & після лікування & $3,4 \pm 0,28 * *$ & $4,7 \pm 0,42$ & $4,9 \pm 0,64^{\#}$ \\
\hline \multirow{2}{*}{$\begin{array}{c}\text { МА еритроцитів, } \\
\text { мкмоль/л }\end{array}$} & \multirow{2}{*}{$6,12 \pm 0,25$} & до лікування & $10,8 \pm 0,56^{*}$ & $13,8 \pm 0,62 *$ & $15,7 \pm 0,74^{* / \#}$ \\
\hline & & після лікування & $8,3 \pm 0,38^{* *}$ & $11,7 \pm 0,83$ & $13,6 \pm 0,63^{\#}$ \\
\hline \multirow{2}{*}{$\begin{array}{l}\text { С-реактивний } \\
\text { протеїн, мг/л }\end{array}$} & \multirow{2}{*}{$2,8 \pm 0,22$} & до лікування & $6,4 \pm 0,48^{*}$ & $8,8 \pm 0,56^{*}$ & $10,2 \pm 0,62 *^{* / \#}$ \\
\hline & & після лікування & $4,2 \pm 0,46^{* / * *}$ & $7,4 \pm 0,43^{\mathrm{HB} / *}$ & $8,4 \pm 0,46^{\mathrm{HB} / * / \#}$ \\
\hline \multirow{2}{*}{ ШОЕ, мм/год } & \multirow{2}{*}{$7,2 \pm 0,43$} & до лікування & $8,4 \pm 0,36$ & $16,6 \pm 1,14^{*}$ & $18,4 \pm 0,94^{* / \#}$ \\
\hline & & після лікування & $7,6 \pm 0,74$ & $10,8 \pm 1,16^{* / * *}$ & $14,2 \pm 0,66^{* / * * / \#}$ \\
\hline \multirow{2}{*}{$\begin{array}{l}\text { Лейкоцити перифе- } \\
\text { ричної крові х109 }\end{array}$} & \multirow{2}{*}{$6,4 \pm 0,38$} & до лікування & $7,3 \pm 0,36$ & $9,4 \pm 0,42^{*}$ & $11,2 \pm 0,82^{* / \#}$ \\
\hline & & після лікування & $6,2 \pm 0,48$ & $7,2 \pm 0,64 * *$ & $8,2 \pm 0,78^{* * / \#}$ \\
\hline
\end{tabular}

Примітка. *- вірогідність різниці показників з групою контролю (p<0,05-0,01); ** - вірогідність різниці показників до і після лікування $(\mathrm{p}<0,05)$; \# - вірогідність різниці показників 3 хворими 3 мінімальними явищами коморбідності $(\mathrm{p}<0,05)$; нв - невірогідність даних до і після лікування в групі

нізмі в період загострення (табл.2), у хворих на ОА у віці до 50 років вірогідно перевищували значення у ПЗО лише за параметром СРП, хоча інші показники тільки незначно перевищували верхні межі референтних коливань у ПЗО. Проте зі зростанням явищ та вираженості коморбідності показники СРП суттєво зростали (у 2-3 рази), включаючи вірогідно вищі значення, ніж у пацієнтів із ОА до 50-річного віку $(\mathrm{p}<0,01)$. Меншою мірою відображав запальний процес ШОЕ: за давності ОА до п'яти років та у віці до 50 років цей показник не перевищував аналогічного у ПЗО, а зі зростанням рівня і вираженості коморбідності ШОЕ вірогідно збільшувалося лише до помірних у загальноприйнятому значенні. Також менш інформативними були показники лейкоцитів: незначний лейкоцитоз при зростанні проявів коморбідності в осіб старше 60 років.

Оскільки дослідження зазначених явищ у хворих на ОА дали нам лише певну інформацію, яку неможливо оцінити однозначно, важливим вбачалося вивчення зворотності метаболічних процесів упродовж одномісячного терміну лікування за стандартними методиками з необхідними доповненнями лікування коморбідних захворювань. За результатами цих досліджень (табл. 2) встановлено, що у хворих на ОА у віці до 50 років (давність захворювання на ОА до п'яти років, переважно олігоостеоартроз із низьким рівнем коморбідності) з настанням стану неповної клінічної ремісії в крові за більшістю показників проі антиоксидантної систем крові (за винятком активності глутатіон-пероксидази та МА еритроцитів) практично досягнуто їх рівня у ПЗО. У той же час у пацієнтів у віці старше 50, особливо 60 років (зростання проявів ОА, тяжкості його перебігу, збільшення рівня та вираженості коморбідних процесів), за той же період лікування з доповненнями явищ коморбідності відмічена лише тенденція до зменшення явищ оксидативного стресу за всіма параметрами. Слід відзначити, що клінічно (оцінка ефективності лікування здійснювалася також за візуальною шкалою - ВАШ), зменшення проявів ОА важко було оцінити як неповна ремісія (показник ВАШ до лікування дорів-

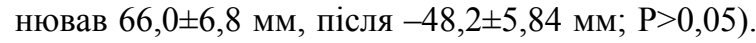
Динаміка параметрів крові з оцінки запального процесу (табл. 2) також засвідчила торпідну зворотність явищ запалення залежно від рівня коморбідності: при низькому рівні коморбідності та проявів і поширеності ОА (хворі віком до 50 років) параметри ШОЕ, лейкоцити та СРП не пере- 
вищували аналогічних у ПЗО; однак із зростанням рівня вираженості коморбідних процесів та проявів ОА показник СРП мав лише тенденцію до покращення, у половини пацієнтів віком до 60 років нормалізувалися параметри ШОЕ і лейкоформули (загальний показник ШОЕ $=16,8 \pm 1,53$ мм/год, $\mathrm{P}<0,05$; загальна кількість лейкоцитів знизилась із $9,1 \pm 0,82$ до $7,4 \pm 0,86 ; \mathrm{P}>0,05)$. У хворих старше 60 років лише в третини нормалізувалися параметри ШОЕ і лейкоцитів, зворотність СРП у крові була ще гіршою (табл. 2).

Гендерних відмінностей досліджуваних параметрів про- та антиоксидантної систем крові та запального процесу не відмічено. Стан ремісії захворювань, що складали поліморбідний фон, дозволяв нам зробити припущення про незначний внесок їх у виявленні порушення метаболічних процесів.

Таким чином, у хворих на ОА зі зростанням вікового фону коморбідності та поліморбідності відмічаються значні порушення стану про- i антиоксидантної систем крові, що носять стійкий характер у процесі лікування за стандартних методів із незначною тенденцією до зворотності впродовж одного місяця спостереження. Виявлені певні прямі паралелі резистентності зворотності цих порушень із зростанням віку хворих та клінічної вираженості коморбідних процесів. Явища зростаючого оксидативного стресу у хворих на OA супроводжуються помірними лабораторними ознаками хронічного низькоінтенсивного запалення, що мають такі ж тенденції перебігу.

\section{Висновки}

1. У хворих на остеоартроз зі збільшенням їх віку поряд із зростанням явищ системності уражень суглобів, зростають кількість і вираженість коморбідних процесів, що супроводжується значним порушенням стану про- і антиоксидантної систем крові та помірними лабораторними ознаками низькоінтенсивного запалення.

2. При зростанні тяжкості перебігу остеоартрозу та вираженості вікових коморбідних процесів за стандартних методів одномісячного лікування остеоартрозу відзначається все гірша зворотність порушень параметрів про- і антиоксидантної систем крові, що має певні прямі кореляції 3 клінічними проявами остеоартрозу, коморбідних процесів та показниками низькоінтенсивного системного запалення, при цьому гендерних відмінностей зазначених явищ не встановлено.

3. Виявлені особливості порушень про- i антиоксидантної систем крові у хворих на остео- артроз на тлі зростаючого вікового коморбідного фону можуть слугувати обгрунтуванням тривалого застосування антиоксидантних засобів у комплексному лікуванні.

Перспективи подальших досліджень вбачаємо в апробації антиоксидантних засобів у комплексному лікуванні хворих на ОА з визначенням критеріїв різної тривалості їх застосування залежно від вираженості явищ коморбідності та віку хворих пацієнтів.

\section{Література}

1. Белялов Ф.И. Лечение внутренних болезней в условиях коморбидности / Ф.И. Белялов. - Иркутск, 2013. $303 \mathrm{c}$.

2. Владимиров Ю.А. Перекисное окисление липидов в биологических мембранах / Ю.А. Владимиров, Ю.А. Арчаков. - Наука, 1972. - 252 с.

3. Коваленко В.М. Остеоартроз. Практична настанова / В.М. Коваленко, О.П. Борткевич. 3-тє вид. зі змінами. - К: Моріон, 2010. $-608 \mathrm{c}$.

4. Мещишен І.Ф. Обмін речовин у людини / І.Ф. Мещишен, В.П. Пішак. - Чернівці: Медінститут, 1995. - $193 \mathrm{c}$

5. Мещишен И.Ф. Метод определения активности глутатионтрансферазы в крови / И.Ф. Мещишен. В кн: Применение ферментов в медицине. - Симферополь, 1987. C. $135-136$

6. Національний підручник з ревматології / за редакцією В.М. Коваленка, Н.М. Шуби. - К.: Моріон, 2013. - 672 с.

7. Нові аспекти патогенезу остеоартрозу та шляхи корекції / Н.М. Шуба, Т.Д. Воронова, Т.М. Тарасенко [та ін.] // Укр.ревматол.ж. - 2012. - № 1 (47). - С. 51-58.

8. Остеоартроз и ожирение: клинико-патогенетические взаимосвязи / В.А. Насонова, О.М. Мендель, Л.Н. Денисов [и др.] // Профилакт. мед. - 2011. - № 1. - С. 29-37.

9. Супрун Э.В. Коморбидность при остеоартрозе у пожилых пациентов: выбор тактики лечения / Э.В. Супрун // Рац. фармакотерапия. - 2013. - № 3 (28). C. 47-52.

10. Berenbaum F. Osteoarthritis as an inflammatory diseases (osteoarthritis is not osteoarthrosis!) / F. Berenbaum // Osteoartosis Cartilage. - 2013. - Vol. 21. - P. 16-21.

11. EULAR evidens - based recommendations for the diagnosis of knee osteoarthritis / W. Zhang, M. Doherty, G. Peat [et al.] // Ann. Rheum. Dis. - 2010. - Vol. 69. P. 483-489.

12. Kadam V.T. Clinical Comorbidity in Osteoarthritis: Associations with Physical Function in older Patients in Family Practice / V.T. Kadam, P.R. Oroft // J. Rheumatol. - 2007. - Vol. 34. - P. 1899-1904.

13. Osteoarthritis: A Disease of the joint as an Organ / R.F. Loeser, S.R. Goldrina, C.R. Scancello [et al.] // Arthritis Rheum. - 2012. - Vol. 64 (6). - P. 1697-1707.

14. Puenpatom R.A. Increased prevalence of metabolic syndrome in individuals with osteoarthritis: an analysis of NHANES III data / R.A. Puenpatom, T.V. Victor // Postgrad. Med. - 2009. - Vol. 121 (6). - P. 9-20.

\section{СОСТОЯНИЕ ПРО- И АНТИОКСИДАНТНЫХ СИСТЕМ КРОВИ У БОЛЬНЫХ ОСТЕОАРТРОЗОМ СКВОЗЬ ПРИЗМУ ПОЛИ- И КОМОРБИДНОСТИ В ВОЗРАСТНОМ АСПЕКТЕ}

\section{Л.А. Волошина}

Резюме. В статье исследовано особенности изменений параметров про- и антиоксидантной систем у 120 больных остеоартрозом (OA) в контексте возрастных явлений коморбидности и полиморбидности в течении месячного срока стандартного лечения. Установлено, что с увеличением возраста больных ОА наряду с ростом системности 
поражений суставов и тяжестью течения ОА растет количество и выраженность коморбидных процессов, среди которых наибольшее внимание предоставлено составляющим метаболического синдрома. В период обострения ОА у всех больных отмечено значительные проявления оксидантного стресса, которые в течение месячного срока лечения при низком уровне коморбидности и в возрасте до 50 лет характеризовались хорошей возвратностью. При росте количества и выраженности коморбидных процессов и в возрасте старше 50 лет отмечалась возрастающая резистентность к возвратности параметров про- и антиоксидантных систем крови. Такую же тенденцию отмечено по показателям системного низкоинтенсивного воспаления. Гендерных различий изменений исследуемых параметров не отмечено. Обосновывается потребность в дополнительном применении антиоксидантных средств в комплексном лечении больных ОА с явлениями растущего числа и выраженности коморбидных процессов.

Ключевые слова: остеоартроз, коморбидность, оксидантный стресс, лечение.

\section{STATUS OF PRO- AND ANTIOXIDANT BLOOD SYSTEMS IN PATIENTS WITH OSTEOARTHROSIS IN THE LIGHT OF POLI- AND COMORBIDITY IN AGE ASPECTS}

\section{L.O. Voloshyna}

Abstract. The author of the article explored in the blood of patients with osteoarthritis (OA) changes of pro- and antioxidant systems parameter features in the context of age, poli- and comorbidity phenomena during one-month period of standard treatment.

Material and methods. In 120 patients with OA of different comorbidity age manifestations parameters of prooxidant (malonic aldehyde) and antioxidant (glutathione restored, the activity of glutathione-S-transferase, glutathione peroxidase) blood systems, C-reactive protein of blood in dynamics during the one-month period of treatment with standard methods have been investigated.

Results and discussion. It was established that with increasing age of patients with OA, along with increasing systemic lesions of joints and severity of OA number and severity of comorbid processes is growing, among which the most attention is given to phenomena that form the metabolic syndrome. During the acute period of OA in all patients significant manifestations of oxidative stress were noted. But during the one-month period of treatment at low levels of comorbidity and at the age of 50 years it was characterized by good reversibility. With the increasing number and severity of comorbid processes and in the age of 50-60 years growing resistance to the repayment options of pro- and antioxidant systems of blood was recorded. The same trend on indicators of low systemic inflammation was observed. Gender differences of change in the parameters were not present. The need for additional use of antioxidant drugs in the treatment of patients with $\mathrm{OA}$ and growing number and severity of comorbid processes has been substantiated.

Key words: osteoarthritis, comorbidity, oxidative stress, treatment.

Higher State Educational Institution of Ukraine "Bukovinian State Medical University" (Chernivtsi)

Рецензент - проф. В.К. Тащук

Buk. Med. Herald. - 2015. - Vol. 19, № 4 (76). - P. 45-50

Надійшла до редакції 08.10.2015 року

(с) Л.О. Волошина, 2015 